\title{
DEVELOPING SUPPLEMENTARY READING MATERIALS FOR THE STUDENTS OF EIGHTH GRADERS NURUS SALAFIYAH PROBOLINGGO
}

\author{
Zainuddin \\ (zainuddintutik@gmail.com)
}

\section{Universitas Maulana Malik Ibrahim Malang}

\begin{tabular}{|c|c|}
\hline ARTICLE & ABSTRACT \\
\hline Keywords: & Developing Supplementary Reading Materials for the students of eighth \\
\hline Supplementary & $\begin{array}{l}\text { Graders at Nurus Salafiyah Probolinggo. It modified Latief model (2009); the } \\
\text { researcher developed material based on data analysis taken from a preliminary }\end{array}$ \\
\hline Reading Material, & $\begin{array}{l}\text { study. The material was validated and tried-out to class VIII-B of Nurus } \\
\text { Salafiyah Probolinggo. The result showed that this study and the product have }\end{array}$ \\
\hline Reading, & $\begin{array}{l}\text { successfully answered the students' needs in reading skills. Therefore, the } \\
\text { product could be used for the eighth-grader students of Nurus Salafiyah }\end{array}$ \\
\hline VIII Grade & Probolinggo \\
\hline
\end{tabular}

\section{INTRODUCTION}

Among other language skills, reading is an essential skill for academic purposes in second language acquisition. A lot of foreign language teaching often emphasize on reading activities. Therefore, various pedagogical purposes help reading to receive this particular focus. For example, national examination (UN) in junior high school level emphasize the reading comprehension skill. Most items in national examination in junior high school are related to reading comprehension. It means that the student in junior high school level should have reading comprehension well concerning the preparation for the national examination and to continue to a higher level of education.

This research is conducted in the eighth-grader at Nurus Salafiyah Probolinggo because the students of that level show the low mean scores in almost all text reading of middle test and final examination are the proof of the students have lack of reading skill. Even, some students do not like to read English reading material because they think that the Language used in the available reading materials are too difficult for them. Based on this condition, the teachers have to find ways to solve the problem. 
Reading skill plays a vital role in the English learning process, especially when students have to deal with the final examination, which includes reading and writing skills. Reading is an ability to draw meaning from the printed page and interpret this information appropriately. So, the critical aspects of acquiring by the students of junior high school are vocabulary and grammar since they are still in the primary stage of learning and have a lack of vocabulary, or it is called as the lower-level reading process (Grabe, W. \& Fredricka L. Stoller, 2002).

To have excellent reading skills, students need to receive ample reading input or many reading materials. According to Krashen (2003), the learner needs to be exposed to a large amount of comprehensible input in their new Language in order to acquire the Language. These reading inputs are not only in the intensive reading activity but also in the extensive reading activity where the student can read freely inside or outside the classroom. Harmer (2007:283) assert that students need to be involved in both intensive and extensive reading to obtain a reading benefit. It is because that the teacher develops students reading materials, logically the materials selected for the module should be able to trigger students' motivation to read.

According to the statement of the problem, the purpose of this study is producing a book about Supplementary Reading Materials to help students with reading skills, especially to the eighth Graders of at Nurus Salafiyah Probolinggo. As it stated in Cunningsworth (1995) that supplementary material primarily graded book expected to answer the disadvantage of a coursebook that is improving varieties in teaching procedures, responding individual student needs and problems, and also improve the creativity in teaching technique and Language

The final product is the final product of this development is in the form of a book entitled "let us read" supplementary reading material for the eighth-grader." The cover of the book is layouted in a bright blue color with which a girl surrounds the globe. Two people are reading on the left side and reading on the right side. The second part is the title of supplementary that followed by the name of the writer, layout, illustrate, cover design, edition, and year. The third part is preface; it describes the reason why supplementary reading material is developed and the aim of providing a supplementary reading. Next is to the teacher; it introduces the content of the product. It is followed by a list of content and continued with the map of the content. The next part is the materials staring with Unit 1 till unit 3 , in each unit, provides a meaningful picture and the objectives of instructional activities. The last part is the answer key and teacher guide. 
The result of the study would be useful for the English teacher of Nurus Salafiyah Probolinggo and other English teachers in other schools to overcome the problem of reading and students' difficulty in reading skills. This study can also become one of the guidelines for teachers and further researchers who will develop other supplementary materials. The result of this supplementary material is also expected to complement the corresponding materials of reading in the coursebook.

The product is developed based on the assumption that the supplementary materials are suitable for the students to need and interest. Also, the material can improve the students reading ability. It is based on Crawley \& Mountain (1995) suggests that material adjustment can be made in several ways; one of them is supplementary reading. It is essential to use reading in the content areas. Supplementary reading should be a compilation of sources such as pictures, books and trade books (Roe, Stood, and Burns, 1995). They state that supplementary reading can develop critical thinking skills, to make a connection between reading and writing, and to develop vocabulary.

The supplementary materials focus on the topics about fantasy; legend, fairy tale, and fable, then is about experiences: holiday to Bali and vacation to Jogja, and the last is autobiography; R.A Kartini, Soekarno, Hatta. Based on the result of the preliminary study, topics mostly are rarely used in the reading text of the coursebook. Also, students only have less reading English text about stories are such as princess Mandalika, Aji Saka, a gift from daughter, the little mouse. So, those stories are expected to motivate the students to read many more stories by focusing the material development on the topics.

The definition of supplementary material is the material that supports the primary coursebook usage. The contents are only additional materials, which support and give reinforcement for the proposed and selected materials in the coursebook. Reading text materials is an interactive activity that consists of the colorful picture, match the picture, match picture into good paragraphs, match picture in jumble paragraph, WH-question, Yes/No question. They are used in the eighth grade of Nurus Salafiyah Probolinggo. 


\section{METHOD}

The researcher decided to adapt Latif (2009) model and procedures of development, as displayed in Figure 1.1.

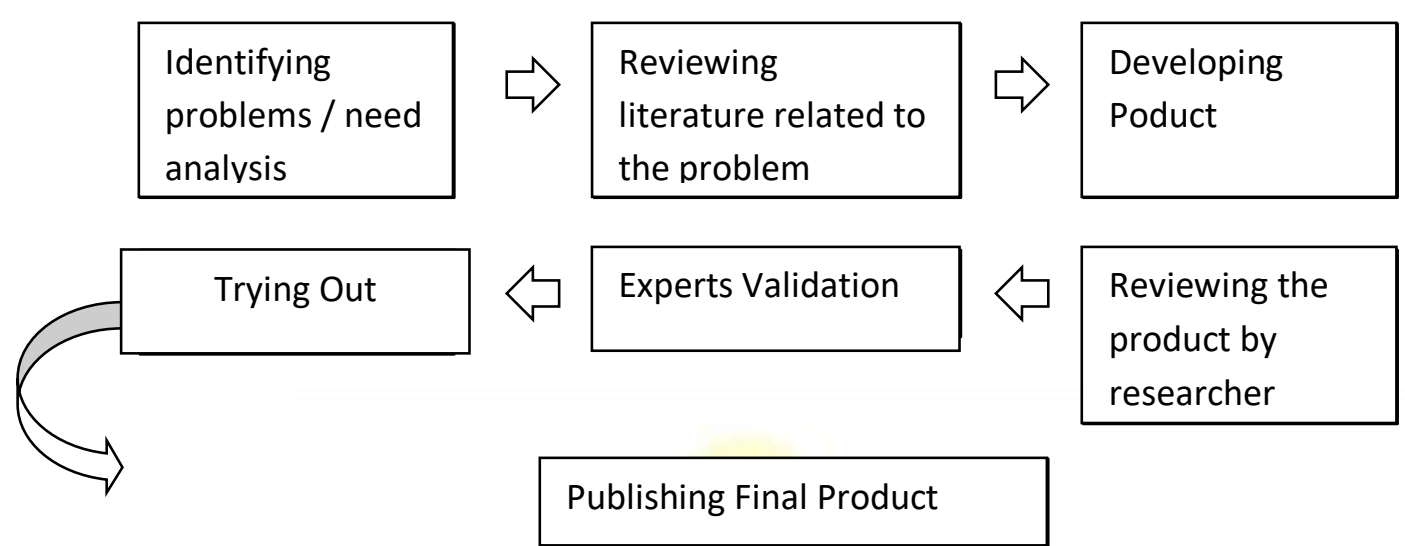

In this study, need analysis is the first step in the process of development. The study was conducted to obtain information as much as possible from a foundation, a principal, corresponding teachers, and the students in the eighth-grader of Nurus Salafiyah Probolinggo. The information related to the existence of reading materials, the problems they have, and their hope related to reading materials are needed for developing appropriate supplementary reading materials for students in eighth-grader of Nurus Salafiyah Probolinggo.

To gather the data in need analysis, the instrument used were the interview guide and the questionnaire. The interview guide was used to interview English teachers. The researcher also had an interview and distributed a questionnaire to the students in eighth-grader of Nurus Salafiyah Probolinggo.

The questionnaire items were presented in relation to the students' reading habits of reading materials in the school. The content of reading materials contains likes and dislikes, the need for Islamic reading materials, and the criteria of the supplementary reading materials for students in eighth-grader of Nurus Salafiyah Probolinggo.

After knowing much information about the problem the students have, the hope and their expectation, and developing materials, the next step is reviewing some related literature. The focus in this reviewing literature is finding some criteria from many experts about good supplementary 
reading materials. The reading materials should (1) be interesting and understandable, that is ane minus level or below the students' linguistics ability (Bamford, 1998). Also, they use simplified texts in the use of controlled vocabulary that what nation (2002) calls grade graders. The materials should help the students gain pleasure from reading, introduce new vocabulary and grammatical feature incidentally (Nation, 2002), (4) suitable with the need interest of the students will find interesting, and the teaching goals (Nutal, 1996) cited in Brown 2007: 374), (5) easy that the students does not need to open dictionary (Ono et. Al, 2004), (6) culturally appropriate and suitable with the value the students have (http://elt-resourceful.com).

The next procedure of this study is developing materials. The development of the materials will be based on the information the researcher got from the need analysis. The materials that wanted to be developed in this study are reading materials for the extensive reading activity for students in eighth-grader of Nurus Salafiyah Probolinggo. The reading materials should be easy to understand, attractive, engaging, and containing Islamic messages.

In developing materials, the researcher selects many reading materials from the internet. The materials are then classified into five types of text. They are about fantasy: the stories of legend, fable, and fairytale, experiences: study tour to Bali and vacation to Jogja, and autobiography: R.A Kartini, Soekarno, Hatta, Soedirman.

There will be some editing and simplifying process for the text that uses difficult words. There will also be a little reading comprehension activities such as true-false and matching the pictures and sentences in this product of development.

After the product is developed and before the experts validate it, the researcher read, check and recheck whether there still inappropriate materials in terms of the Language (vocabulary and misspelling), the content, the topic.

After that, Experts are selected to improve the quality of the product. So anybody who is considered needed to improve the quality of a product can be selected as the experts for the validation (Latief, 2009). The experts must be the ones who are experienced in the era. In the expert validation of this study, the researcher will include two experts. The experts validate the Language are: English teacher at Nurus Salafiyah Probolinggo paying and the lecturer of English (Islamic University of Malang). 
The next step is try-out. The try-out is intended to get feedback from the field subject. The try-out texts are done to collect data that apply to read materials in terms of difficulty, usefulness, and effectiveness. It is also used to point the area of inappropriateness needed to be revised. The Try-out in this study is conducted by giving the students the supplementary reading materials to be read and the researcher as them to give comments and suggestions. The subject of try out will be the students of Islamic junior high school Nurus Salafiyah Probolinggo

The experts and students evaluate the revision of developed materials after the materials being validated by the experts and being tried out to students. There will be at least twice a revision. The first product revision is done after having expert validation. After having try-out, there will be a second revision and improvement of the product that is not suitable for the students or not friendly users to be a better final product.

The last step of the development study is publishing products. The product will be printed (by publisher) and published in many copies to fulfill the students' needs.

\section{RESULT OF DEVELOPMENT}

The result of the try-out consists of the data from the first expert (E1) is an English teacher, and the second expert (E2) is lecturer (Islamic University of Malang). The results of the validation were explicated as follows;

\section{The Good Points}

The first was the design and layout. E1 and E2 are graded as "good" according to four criteria; (1) the cover is attractive to the students, (2) The layout is excellent and attractive to the students, (3) The typing is clear, neat and regular, (4) The use of letter is clear, appropriate, consistent, and readable.

The second was about the topic. It was remarked "good" by E1 and E2 in three subcomponents; (1) the topics are interesting, (2) the topics are various, (3) the topics are ordered appropriately.

The third was the instructional objective. According to both E1 and E2, this aspect was scored "good" follows some criteria: (1) The instructional objectives are clear, (2) The 
instructional objects are stated appropriately, (3) The instructional objectives are ordered appropriately.

The fourth was the text. Both the expert one and expert two agreed to say "good" for the points: (1) the texts can develop the reading skill, (2) the text can be exploited into communicative tasks.

The fifth was the content. E1 and E2 are graded "good" based on criteria: (1) The content is explicit, (2) The content is suitable to the objective of teaching and culture, (3) The students can understand the content.

The sixth was the task. E1 and E2 claimed that the tasks are appropriate to the given context, and the students can do the task. So, both of them are graded as "good."

The seventh was activities. Between expert one and expert two, they had the same perception to say "good." It is according to three sub-points: (1) the activities are appropriate to the given context, (2) the number of activities in each chapter is sufficient (3) the activities can interestingly trigger the students' motivation.

The eighth was Language. Based on the expert one and expert two, they agreed to grade "good" for sub-point; the Language is clear and easy to understand.

Besides the good points described above, there were some adequate points from expert one and expert two grades. Those describe as follow:

\section{The adequate point}

The first was related to design and layout. E1 and E2 are graded as "adequate," according to the illustration, is interesting. The second was the organization of the materials. It was remarked "adequate" by E1, and E2 relates to three criteria; (1) The material is organized attractively, (2) The organization of materials in the form of units and sections are appropriate, (3) The materials are organized in logically order task. The third was the text. Based on both E1 and E2 ideas, this aspect was graded as "adequate" because of the number of texts in each chapter is sufficient. The fourth was the vocabulary. Both of the experts agreed to say that the selection of vocabulary is appropriate for the target learners, and the chapters cover sufficient activities related to vocabulary use. The fifth was the task. E1 and E2 are graded "adequate" based on criteria; The tasks are simple 
and clear. The tasks can integrate knowledge by the students about the topics and the Language they learn. The sixth was activities. E1 and E2 claimed that the activities integrate knowledge and the target language. So both of them are graded as "adequate". The seventh was Coverage of materials; both experts said The materials are relevant to the students' needs and interest, and the materials are suitable for the students' level. The eighth was Language. Both experts agreed to grade "adequate" in line with The Language that is suitable to the level of students.

From what the experts had already been determined, the product is categorized valid. Nevertheless, the product still needs some revision to come to better materials before the product is tried-out.

\section{FINDINGS AND DISCUSSION}

The appropriate topics which had been developed for Supplementary Reading Materials for the students of eighth Graders of Nurus Salafiyah Probolinggo based on student's needs that involve the topics: legend, experiences, and autobiography. Furthermore, additional reading topics need to be developed in order to supply the missing materials which were required by the students. This idea is also supported by (1998), who stated that a good reading material should be contextualized to topics and themes that provide meaningful, purposeful uses for the target language.

The product of this study has already fulfilled all requirements of what is so-called a good reading material since it was constructed by considering the criteria of good material from Tomlinson (1998)). A contextual material is a must, wherein activities. It means that all materials should be exciting topics and themes that provide meaningful, purposeful uses for the target language. As one example has been provided in the product, the material is presented on the topic of "Princess Mandalika. This instance is a legend from Lombok. Suitable materials should be attractive. All materials presented in this product could stimulate interactions and be generative in terms of language meaning. Then students can do interaction and generate learning language through the activities. Also, this product could encourage the students to develop learning skills and strategies which integrate a part of the development of the product. All materials could provide motivated students to learn something from the reading material where they will know about the form of the text and also the function of the text through reading. 
The integration of language use was also considered in the production of this product, so it will allow the student to integrate the language skills and improve their language quality. In terms of authenticity, all reading materials were taken from an internet source. Furthermore, to attract students' attention, all materials are presented in a beautiful form and also an attractive topic, because the selection of the material should be based on attractive topics too.

About the design of material or the presentation of material, excellent and explicit instruction is also provided to guide students to work through the reading materials. As a fundamental consideration, this product matches with the curriculum. The production of this product also considered the competency standard so that it matches with the curriculum. Moreover, the presentation of the materials is also typed neatly and has subheadings. The subheadings are bolded and given different colors. Consistent with the font point, space and text, assignment, exercises, and feedback, in every unit is presented by using appropriate pictures, bold or italic text. One more important thing to attract the first sight to this product, a beautiful cover was designed, and all the arrangements of the activities, including all contents, were arranged well. All of what have been mentioned before, especially designing color; shape etc. were conducted to attract students feeling in reading. In a nutshell, by fulfilling all requirements of a kind product from Tomlinson (1998), which have been summed up before, the product of this study can be considered as a functional product of reading materials.

\section{CONCLUSION}

This study appertained to developing an educational product that was reading supplementary materials for reading activity at the eighth graders of Nurus Salafiyah Probolinggo. The final product of the development was a book entitled "Lets Read" for reading activity. It contains various simple text-types, relevant illustrations, exercises, and critical answers to the exercise for independent study.

At the need assessment step, the researcher found out that most of the students in VIII-B class in Nurus Salafiyah Probolinggo faced difficulty in vocabulary items. That such difficulty was worsened by the texts which were too lengthy and some uninteresting topics laid in the commonly published coursebook. Besides, the English teacher, who was the interviewee, also stated that most of her students had a problem with vocabulary. However, it can be solved as long as the materials provided were able to bring attraction and curiosity to them. 
After administering the need assessment and followed by materials development, the materials were validated by the first expert (E1) and the second expert (E2). Both E1 and E2 generally stated that the product is worth using. It was because most of the texts included are able to expand student's knowledge, as well as the activities provided, are not quite burdensome. The teacher, moreover, stated that it was great to motivate the students to learn English through extensive reading activity by providing such a product. Most importantly, she further asserted that the Language used is below the students' level of difficulty since they have to read it independently.

At the try-out of the product phase, most of the students came to their comfort-zone while reading. Most of the students were fascinated and felt curious about the text. Once, a student mentioned that he had already been attracted only by reading the title of the text. Another student also commented that the texts were fun and exciting so that at the moment of reading, she did it seriously at the same time felt comfortable. Additionally, this product promotes edutainment activities. It means that any contents of this product focus on educating students as well as entertaining them.

\section{REFERENCES}

Anonymous. (2012). Tips for selecting effective, authentic reading materials.http://eltresourceful.com. Accessed on January 72013

Brown, H.D. (2007). Teaching by the principle: An Interactive Approach to Language Pedagogy. Third Edition. New York. Pearson Edition

Bamford. (1998). Extensive Reading in Tshe Second Language Classroom. Cambridge: Cambridge University Press

Cunningsworth, A. (1995). Coursebook. London: Macmillan Heinemann (English Language Teaching)

Diknas. Standar Isi dan Standar Kompetensi Lulusan Tingkat Sekolah Mengeah Pertama dan Madrasah Tsanawiyah Peraturan Mendiknas No. 22, No. 23 dan No. 24 th. 2006. 2006. Jakarta: PT Binatama Raya

William, G. \& Stoller, F. L. (2002).Teaching and Researching Reading. London: Pearson Education Longman.

Guo.S. (2012). Using Authentic Materials for Extensive Reading to Promote English Proficiency. English Language Teaching; Vol.5, No.8 Canadian Center of Science and Education.

Harmer, J. (2007). The Practice of English Language Teaching. London. Longman 
Yuen, K. (2011). THE Representation of Foreign Cultures in English Textbook. ELT Journal Volume 65/4, Oxford University Press.

Krashen.S. (2003) .Exploration in Language Acquisition and Use. Portsmouth Heinemann.

Kelly, C. (2002). Effective Ways to Use Authentic Matrials with ESL/EFL student. The internet TESOL journal, Vol.VIII, No 11, November 2002. Retrieved from http:/iteslj.org

Latief, A. (2009). Educational Research \& Development. On line Publication. University of Pittsburg and Universitas Negeri Malang. Accessed on January 2014.

Lynch, L. (2012). Throw Away The Course Book and Adapt Authentic Material.retrieved at February 26, 2013 from http://www.eslbase.com/article/authentic-materials-2

Martinez, A.G. (2002). Authentic Materials: an Overview,Karens Linguistics Issues, retrieved February 26, 2013 from http://www3.telus.net/linguistics issues/authentic-materials.html

Nation, P. (2002). Managing Vocabulary Learning.RELC portfolio series. Orange grove read: SEAMAO Regional Language Center

Nunan, D. (1991). Designing Tasks for Communicative Classroom. Sydney: Cambridge University Press.

Ono, L and R, R day and K harsh. (2004). Tips for Reading Extensively. English Teaching Forum. October 2004.

Ribahan. (2008). Developing Reading Comprehension Materials for Students of Economic Department State Institutes of Islamic studies Mataram. State university of malang. Unpublished thesis

Richards, J. (2001). Curriculum development in language education. Cambridge: Cambridge University Press

Richard,J.C., \& Roger, T.S. (2001). Approaches and method in language teaching. Cambridge: Cambridge University Press.

Rohmah, Z. (2009). EFL Materials in Madrasah Tsanawiyah: what do they really need. TEFLIN journal, 20 (1) 104-117.

Rohmah, Z. (2012). Incorporating Islamic Message in The English Teaching in the Indonesia Context, International journal. Social scince \&education 012 vol. 2 issues 2.

Tarmizi, R. (1999). Reading Material for Pondok Pesantren Darul Hikmah Peunangga Reuk Meulaboh Aceh Barat. Universitas Negeri Malang: Unpublished thesis.

Tomlinson, B. (1998). MaterialsDevelopment in LanguageTeaching. U.K: Cambridge University Press.

Yalden, J. (1985). The Communicative Syllabus Evolution, Design and Implementation. Emford: NY. Pengamon Press 